\title{
ANTIFUNGAL ACTIVITY AND CHEMICAL CONSTITUENTS OF THE ESSENTIAL OIL FROM LEAVES OF Nectandra longifolia (Ruiz \& Pav.) Nees
}

Fecha de recepción: 20 de enero de 2016 • Fecha de Evaluación: 06 de marzo 2016 • Fecha de aceptación: 14 de marzo de 2016

\section{ACTIVIDAD ANTIFÚNGICA Y CONSTITUYENTES QUÍMICOS DEL ACEITE ESENCIAL DE LAS HOJAS DE Nectandra longifolia (Ruiz \& Pav.) Nees}

Daniel Plazas-Jiménez', Víctor Macias-Villamizar², Ericsson Coy-Barrera ${ }^{3 *}$

\section{ABSTRACT}

"Yellow moena" (Nectandra longifolia: Lauraceae) is a fragrant leaves-possessing plant commonly used for timber purposes. Nevertheless, so far, there is not available information about its chemical composition. Thus, in the present work is described the components of the essential oil from N. longifolia leaves. The oil was extracted by steam distillation and analyzed by GC/FID and GC/MS. Twenty eight compounds were therefore identified. The main components were found to be terpinen-4-ol (53.1\%), $\alpha$-terpinene (6.8\%), $\alpha$ -phellandrene (4.5\%), and $\beta$-pinene (3.8\%). The chemical composition of essential oil from N. longifolia leaves was consequently in agreement to that of several neotropical Lauraceae plants. In addition, the oil exhibited good antifungal activity against $F$. oxysporum through dose-dependent mycelial growth inhibition (using amended media and fumigant assays).

Keywords: Lauraceae, Nectandra longifolia, essential oil, monoterpenes.

1 Universidade Federal de Goiás (UFG), Goiânia, Brasil.

2 Universidad del Magdalena, Santa Marta, Colombia.

3 Universidad Militar Nueva Granada, Cajicá, Colombia. *corresponding author. E-mail: inquibio@unimilitar.edu.co 


\section{RESUMEN}

La "moena amarilla" (Nectandra longifolia, Lauraceae) es una planta con hojas fragantes que comúnmente se utiliza para propósitos maderables. Sin embargo, a la fecha, no hay información disponible sobre su composición química. Por consiguiente, en el presente trabajo se describen los componentes del aceite esencial obtenido a partir de las hojas de N. longifolia. El aceite se extrajo por destilación por arrastre con vapor y se analizó por CG/FID y CG/EM. De esta manera se identificaron veintiocho compuestos como componentes del aceite obtenido, cuyos principales fueron terpinen-4-ol (53.1\%), $\alpha$-terpineno (6.8\%), $\alpha$-felandreno (4.5\%), and $\beta$-pineno (3.8\%). La composición química del aceite esencial de las hojas de N. longifolia fue consecuente con aquellas registradas en aceites de otras plantas neotropicales de la familia Lauraceae. Adicionalmente, el aceite exhibió actividad antifúngica frente a F. oxysporum a través de inhibición del crecimiento micelial dependiente de la dosis (usando ensayos de medio suplementado y acción fumigante).

Palabras Clave: Lauraceae, Nectandra longifolia, aceite esencial, sesquiterpenos.

\section{INTRODUCTION}

Lauraceae is a family of plants mainly distributed in tropical and subtropical regions and composed by 52 genera and nearly 3000 species (Chanderbali et al., 2001). The Lauraceae family is well-known for its role in traditional medicine and common uses (van der Werff and Richter, 1996) and for those phytochemical studies performed on lauraceous plants finding several metabolites, including alkaloids, lignans, neolignans, and flavonoids (Pagotto et al, 1998) with important biological activities (Oliveira-Filho et al., 2015). Plants of this family are also recognized to produce fragrant materials, because of that a plethora of studies had been conducted in order to determine the composition of essential oils of several Lauraceae specimens (Takaku et al., 2007).

Nectandra genus (Lauraceae) is considered endemic in neotropical regions (Macías-Villamizar et al., 2015) with occurrence from Florida to Argentina but predominantly found in South America (Cicció et al., 2009). The plant list (www.theplantlist.org; accessed on 26 march 2016) includes 357 scientific plant names at species level for the genus Nectandra, but 117 are considered as accepted names and the other 184 as synonyms (Macías-Villamizar et al., 2015). In Colombia, thirty four species are known, distributed especially in zones below $1800 \mathrm{~m}$. N. longifolia, known in Colombia as "yellow moena", can be found in Amazonia and Orinoquia regions. It is found in areas with high and constant rainfall, but also in areas with a marked dry season. Its wood is considered as a good quality material, soft, lightweight, fairly durable; because of that It is prized in carpentry, cabinet making and construction. Despite its fragrant leaves, this plant has no background in essential oil composition studies; therefore the exposed information herein is reported for the 
first time as well as the antifungal activity against Fusarium oxysporum, a commercially-important phytopathogen. Thus, in this paper is presented the chemical and biological analysis of the N. longifolia-derived essential oil as prospecting parameter for further studies with this plant.

\section{MATERIALS AND METHODS}

\section{Plant Material}

Leaves of $N$. longifolia were collected in Casanare, Colombia (coordinates: +5.183, -72.532) in March, 2012. A voucher specimen, numbered COL528624, has been deposited at the Herbario Nacional Colombiano of the Instituto de Ciencias Naturales - Universidad Nacional de Colombia.

\section{Essential oil extraction}

Dry leaves (122 g) were finely chopped and steam distilled for $2 \mathrm{~h}$ to obtain the essential oil, which was dried over anhydrous sodium sulfate affording the crude oil (0.045 g).

\section{Chemical Analyses}

GC/FID. This analysis was carried out on a Shimadzu GC-17A gas chromatograph equipped with a FID and operated in split mode (1:15, injected volume 1 $\mu \mathrm{L})$, using a fused silica capillary column HP-5, $30 \mathrm{~m} \times$ $0.25 \mathrm{~mm}, 0.5 \mu \mathrm{m}$ coating thickness. The operational conditions used were as follows: temperature program from $50^{\circ} \mathrm{C}(4 \mathrm{~min})$ to $300^{\circ} \mathrm{C}(20 \mathrm{~min})$ at $4^{\circ} \mathrm{C} / \mathrm{min}$, split/splitless injector $\left(300^{\circ} \mathrm{C}\right)$, carrier gas was helium at $1.0 \mathrm{~mL} / \mathrm{min}$, and makeup gas was nitrogen at 30 $\mathrm{mL} / \mathrm{min}$. Quantitation was made by using the Class 5000 software. Relative percentages were calculated by electronic integration of FID, whose peak areas were used without response factor correction. Retention indices (RI) were calculated in order to support the identification using linear hydrocarbons $\left(\mathrm{C}_{8}-\mathrm{C}_{24}\right)$ (certified standard, Supelcoß).
GC/MS. This analysis was carried out on a Shimadzu GC-17A gas chromatograph coupled to a Shimadzu GCMS-QP5050A mass spectrometer (70 eV) using a fused silica capillary column HP-5ms, 30 $\mathrm{m} \times 0.25 \mathrm{~mm}, 0.5 \mu \mathrm{m}$ coating thickness, using identical program temperature as GC/FID. Interface temperature $300^{\circ} \mathrm{C}$. Detector voltage: $1.20 \mathrm{kV}$. Acquisition mass range: 42-800u. Acquisition mode: full scan; scan interval: $0.35 \mathrm{~s}$. Solvent delay: $3 \mathrm{~min}$. The components of the oil were identified by detailed/ extensive analyses of their mass spectra, by comparison with those of the compound library (NIST02) and by comparison of their experimental retention indices (RI) with those reported (Adams, 2007).

\section{Antifungal Assays}

The phytopathogen Fusarium oxysporum was obtained from a commercial culture of Cape gooseberry (Physalis peruviana) in the department of Cundinamarca, Colombia. The fungus was cryopreserved in nutrient broth: glycerol $70: 30$ at $-20{ }^{\circ} \mathrm{C}$ and reactivated in nutrient agar plates at $25^{\circ} \mathrm{C}$ for 48 $h$ for usage. The in-vitro antifungal activity against F. oxysporum was evaluated through the inhibition of mycelial growth by two protocols (i.e., amendedmedium and fumigant assays)

Amended-medium assay. Potato Dextrose Agar (PDA) culture medium was supplemented with the N. longifolia essential oil. The final doses (100-0.01 $\mu \mathrm{g} / \mathrm{mL}$ ) were reached by a direct mixture between the medium (PDA before solidifying) and the oil, adding the required amount of medium and oil for succeeding the required dose to be evaluated. This mixture was vigorously stirred until achieving a homogenous dispersion before solidifying. The amended medium was quickly added into 6-cm Petri dishes and then a 4-mm agar-mycelial plug from actively growing cultures of F. oxysporum was inoculated into the center of the Petri dish (Ochoa-Fuentes et al., 2012). Each trial consisted of a randomized 
design with three replicates compared to a plate control (untreated PDA). Prochloraz ${ }^{\circledR}$ was used as positive control. Petri dishes were sealed with parafilm to prevent the leaking of test oil. After inoculation and sealing, the plates were incubated at room temperature (average, $17^{\circ} \mathrm{C}$ ). Assay was completed once the colony on the untreated dish wholly covered the Petri dish (average, 3 days). Mean colony area $\left(\mathrm{mm}^{2}\right)$ was therefore measured for treated and untreated plates and the percent mycelial growth inhibition (MGI) was then calculated for each replicate. $\% \mathrm{MGI}=$ (mycelial growth area in untreated dish - mycelial growth area in treated dish / mycelial growth area in untreated dish) * 100 .

Fumigant assay. PDA culture medium was placed into 6-cm Petri dishes and then a 4-mm agar-mycelial

Table 1. Essential Oil Composition of N. longifolia leaves.

\begin{tabular}{|c|c|c|c|c|c|c|c|}
\hline No & $\mathbf{R}^{\mathbf{b}}$ & Compounds ${ }^{a}$ & $\%$ & No & $\mathbf{R} \mathbf{l}^{\mathbf{b}}$ & Compounds ${ }^{a}$ & $\%$ \\
\hline 1 & 935 & $\boldsymbol{\alpha}$-pinene & 1.4 & 15 & 1100 & $\beta$-linalol & 0.4 \\
\hline 2 & 944 & camphene & 0.6 & 16 & 1178 & terpinen-4-ol & 53.1 \\
\hline 3 & 972 & $\beta$-pinene & 3.8 & 17 & 1192 & $a$-terpineol & 0.3 \\
\hline 4 & 989 & $\beta$-myrcene & 2.5 & 18 & 1349 & $\alpha$-cubebene & 1.7 \\
\hline 5 & 1003 & $\alpha$-phellandrene & 4.5 & 19 & 1377 & $\alpha$-copaene & 0.7 \\
\hline 6 & 1018 & $\boldsymbol{\alpha}$-terpinene & 6.8 & 20 & 1436 & $\beta$-caryophyllene & 1.1 \\
\hline 7 & 1021 & $\rho$-cymene & 0.6 & 21 & 1498 & bicyclogermacrene & 2.1 \\
\hline 8 & 1039 & limonene & 2.3 & 22 & 1507 & $\beta$-bisabolene & 0.6 \\
\hline 9 & 1028 & 1,8-cineole & 1.9 & 23 & 1512 & $\alpha$-muurolene & 0.7 \\
\hline 10 & 1040 & $\beta$-E-ocimene & 0.9 & 24 & 1529 & $\delta$-cadinene & 1.5 \\
\hline 11 & 1046 & $\beta$-Z-ocimene & 1.5 & 25 & 1550 & $\boldsymbol{\alpha}$-cadinene & 1.2 \\
\hline 12 & 1164 & borneol & 2.4 & 26 & 1605 & guaiol & 0.8 \\
\hline 13 & 1069 & $\boldsymbol{V}$-terpinene & 0.7 & 27 & 1654 & $\alpha$-muurolol & 1.1 \\
\hline 14 & 1084 & $\boldsymbol{\alpha}$-terpinolene & 2.4 & 28 & 1660 & $\boldsymbol{\alpha}$-cadinol & 0.9 \\
\hline \multicolumn{7}{|c|}{ Monoterpene hydrocarbons (\%) } & $12(74.3 \%)$ \\
\hline \multicolumn{7}{|c|}{ Oxygenated monoterpenes (\%) } & $5(11.4 \%)$ \\
\hline \multicolumn{7}{|c|}{ Sesquiterpene hydrocarbons (\%) } & $8(9.6 \%)$ \\
\hline \multicolumn{7}{|c|}{ Oxygenated sesquiterpenes (\%) } & $3(4.3 \%)$ \\
\hline \multicolumn{7}{|c|}{ Total } & 28 (98.5\%) \\
\hline
\end{tabular}

${ }^{a}$ Compounds are listed in order of RI values; ${ }^{b} \mathrm{RI}=$ Retention Indices (experimental) as calculated from retention times recorded on GC using a HP-5 column and a homologous series of $n$-alkanes $C_{8}-C_{24}$, under identical GC conditions. 
plug from actively growing cultures of F. oxysporum was inoculated into the center of the Petri dish. Lids were placed upside down on the Petri dishes. Essential oil was introduced onto an 8-mm paper disc (Whatman $\left.N^{\circ} 4\right)$, which was placed on the agar-free lid of the Petri dish (Kim and Park, 2012). Each 8-mm paper disc was prepared adding oil aliquots (1-50 $\mu \mathrm{L}$ ) in order to attain the corresponding doses within the plates (8-390 $\mu \mathrm{L} / \mathrm{L}$ air). Each trial also consisted of a randomized design with three replicates compared to a plate control (untreated PDA). Petri dishes were then sealed with parafilm. After inoculation and sealing, the plates were incubated at room temperature $\left(17^{\circ} \mathrm{C}\right.$ average). Assay was completed once the colony on the untreated plate wholly covered the Petri dish (average, 3 days). Mean colony area $(\mathrm{mm} 2)$ was therefore measured for treated and untreated plates and the percent mycelial growth inhibition (MGI) was then calculated for each replicate. $\% \mathrm{MGl}=$ (mycelial growth area in untreated dish - mycelial growth area in treated dish / mycelial growth area in untreated dish) * 100 .

\section{Statistics}

Percent MGI values were used to calculate the half-maximal effective doses $\left(E D_{50}\right)$ through non-linear regressions using the software GraphPad prism 5.00 (GraphPad software, San Diego, CA, USA).

\section{RESULTS AND DISCUSSION}

The gas chromatogram of the essential oil obtained by steam distillation from leaves of $N$. longifolia showed the presence of thirty three signals, but twenty eight compounds were found to be the main components (98.5\%). The cumulative relative abundance of remaining signals was below $0.2 \%$. Main compounds were identified by GC/MS and CG/FID (table 1). The main constituents of the essential oil were terpinen-4-ol (53.1\%), $\alpha$-terpinene (6.8\%), $\alpha$ -phellandrene (4.5\%), and $\beta$-pinene (3.8\%) (Figure 1). The oil was found to be rich in monoterpene hydrocarbons (74.3\%) and oxygenated monoterpenes $(11.4 \%)$, being the menthane-containing monocyclic monoterpenes the most abundant moiety in $N$. longifolia leaves-derived essential oil.

So far, no oil from N. longifolia has been described. In addition, despite the several studies performed on oils obtained from plants of other Lauraceae genera (Palazzo et al., 2009; Unlu et al., 2010; Fidelis et al., 2013; Takaku et al., 2007; Chaverri and Cició, 2005; Bruni et al., 2004), the Nectandra plants suffer of a lack of chemical studies performed on their essential oils, since only seven oils from Nectandra plants had been reported (Macias-Villamizar et al., 2015). However, all of these studies coincide that the composition could fluctuate even inter and intra genera, including those plants producing phenylpropanoid-abundant essential oils (Unlu et al., 2010). Additionally, the nature of Lauraceous oils might be divided into monoterpene chemotypes, such as N. angustifolia (Torres et al., 2005), and sesquiterpene chemotypes, such as $N$. antillana (Pino et al., 2014) and N. leucantha (Grecco et al, 2015), including common chemical components such as $\alpha$-and $\beta$-pinene, $\beta$-caryophyllene, bicyclogermacrene, germacrene-D, menthane derivatives, among others (Amaral et al., 2015). Thus, as expected, N. longifolia essential oil shares some components to that of other neotropical Lauraceae plants involving a monoterpene chemotype.

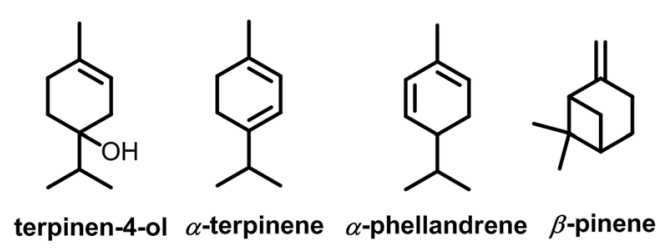

Figure 1. Main components of the essential oil from N. longifolia leaves. 
Some works have described the good antifungal activity of monoterpene-enriched essential oils (Lucini et al., 2006; Parveeen et al., 2013; Tyagi and Malik, 2010; Terzi et al., 2007). Therefore, the in vitro antifungal activity of $N$. longifolia-derived essential oil was evaluated against F. oxysporum, a commercially-important phytopathogen. The activity was evaluated using two protocols (i.e., amended-medium and fumigant assays) in order to assess the capability of the oil for inhibiting the mycelial growth of the phytopathogen. The essential oil exhibited a dose-dependent behavior on both protocols as
$0.12 \mu \mathrm{g} / \mathrm{mL}$ (Morcia et al., 2012). Additionally, there is important evidences that monoterpenes increase the concentration of lipid peroxides producing fungal cell damage (Lucini et al., 2006) or they bind to ergosterol generating a subsequent destabilization of fungal cell membranes (Miron et al., 2014), which explain the inhibition of fungal development showed by monoterpenes as well as by the essential oil from N. longifolia leaves.

In conclusion, the composition of essential oil from N. longifolia leaves no significantly differs from reported data of other Lauraceae plants,
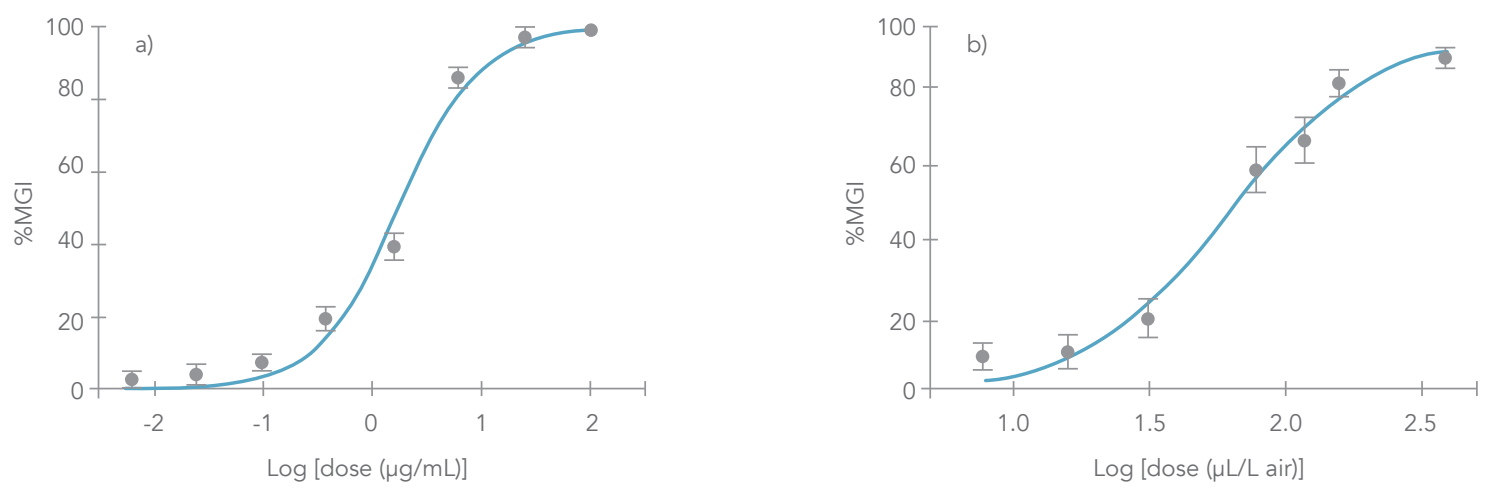

Figure 2. Dose-response curves constructed from the mycelial growth inhibition exhibited by essential oil from N. longifolia leaves through a) amended-medium assay and b) fumigant assay.

observed in Figure 2. ED 50 values could be thus calculated by non-linear regression. The $\mathrm{ED}_{50}$ value for the oil - determined by amended-medium assay was found to be comparable to the positive control, prochoraz $®(1.80 \pm 0.29$ vs $1.68 \pm 0.37 \mu \mathrm{g} / \mathrm{mL}$, respectively), whereas by fumigant assay the $\mathrm{ED}_{50}$ was found to be $61.7 \pm 8.8 \mu \mathrm{L} / \mathrm{L}$ air. The antifungal activity exhibited by $N$. longifolia essential oil can be rationalized by the abundant presence of terpinen4-ol (51.3\%), whose activity was individually assessed against other fungi, affording an $\mathrm{ED}_{50}=0.49 \pm$ constituting this specific oil as a source of monoterpene-type compounds. However, seasonal/circadian/ontogenetic variations should be evaluated, since intrinsic and external factors that affect the oil's content and composition, suggesting an important requirement for further studies involving $N$. longifolia . In addition, the oil exhibited good antifungal activity against $F$. oxysporum with $\mathrm{ED}_{50}=$ $1.80 \pm 0.29 \mu \mathrm{g} / \mathrm{mL}$ and $61.7 \pm 8.8 \mu \mathrm{L} / \mathrm{L}$ air obtained after evaluation through amended-medium and fumigant assays, respectively. The antifungal results 
can be explained by the abundant presence of terpinen-4-ol (53.1\%) as the main constituent of the oil.

\section{ACKNOWLEDGMENTS}

We thank Universidad Militar Nueva Granada (UMNG) for the financial support. This work is a product derived of the Project INV-CIAS-1788 financed by Vicerrectoría de Investigaciones at UMNG - Validity 2015.

\section{REFERENCIAS}

1. Adams RP. 2007. Identification of essential oil components by gas chromatography/mass spectrometry. $4^{\circ}$ ed. Illinois USA: Allured Publishing Corporation, Carol Stream,

2. Amaral LP, Schindler B, Bianchini NH, Longhi SJ, Araújo de Almeida CA, Mallmann CA, Heinzmann BM. 2015. Variabilidad de la composición química del aceite esencial de Nectandra megapotamica (Spreng.) Mez (Lauraceae). Boletín Latinoamericano y del Caribe de Plantas Medicinales y Aromáticas, 14:190-205.

3. Bruni R, Medici A, Andreotti E, Fantin C, Muzzoli MV, Dehesa M, Romagnoli C, Sacchetti G. 2004. Chemical composition and biological activities of Ishpingo essential oil, a traditional Ecuadorian spice from Ocotea quixos (Lam.) Kosterm. (Lauraceae) flower calices. Food Chemistry, 85:415-421.

4. Chanderbali AS, van der Werff H, Renner SS. 2001. Phylogeny and Historical Biogeography of Lauraceae: Evidence from the Chloroplast and Nuclear Genomes. Annals of the Missouri Botanical Garden, 88:104-134.

5. Chaverri C, Cicció JF. 2005. Essential oil of trees of the genus Ocotea (Lauraceae) in Costa Rica. I. Ocotea brenesii. Revista de Biología Tropical, 53:431-436.

6. Cicció JF, Chaverri C, Díaz C. 2009. Volatile compounds of Nectandra salicina (lauraceae) from Costa Rica and their cytotoxic activity on cell lines. Quimica Nova, 32:417-420.

7. Fidelis CHV, Sampaio PTB, Krainovic PM, Augusto F, Barata LES. 2013. Correlation between maturity of tree and GC $\times$ GC-qMS chemical profiles of essential oil from leaves of Aniba rosaeodora Ducke. Microchemical Journal, 109:73-77.

8. Grecco SS, Martins EG, Girola N, de Figueiredo CR, Matsuo AL, Soares MG, Bertoldo Bde C, Sartorelli P, Lago JH. 2015. Chemical composition and in vitro cytotoxic effects of the essential oil from Nectandra leucantha leaves. Pharmaceutical Biology, 53:133-137.

9. Kim E, Park K. 2012. Fumigant Antifungal Activity of Myrtaceae Essential Oils and Constituents from Leptospermum petersonii against Three Aspergillus Species. Molecules, 17:10459-10469

10. Lucini El, Zunino MP, Lopez ML, Zygadlo JA. 2006. Effect of monoterpenes on lipid composition and sclerotial development of Sclerotium cepivorum Berk. Journal of Phytopathology, 154:441-446.

11. Macías-Villamizar VE, Cuca-Suárez LE, CoyBarrera ED. 2015. Genus Nectandra: Phytochemistry and Biological Activity. Boletín Latinoamericano y del Caribe de Plantas Medicinales y Aromáticas, 14:317-342. 
Fevista

12. Miron D, Battisti F, Silva FK, Lana AD, Pippi B, Casanova B, Gnoatto S, Fuentefria A, Mayorga P, Schapoval EES. 2014. Antifungal activity and mechanism of action of monoterpenes against dermatophytes and yeasts. Revista Brasileira de Farmacognosia, 24:660-667.

13. Morcia C, Malnati M, Terzi V. 2012. In vitro antifungal activity of terpinen-4-ol, eugenol, carvone, 1,8-cineole (eucalyptol) and thymol against mycotoxigenic plant pathogens. Food Additives \& Contaminants: Part A, 29:415-422.

14. Ochoa-Fuentes YM, Cerna-Chávez E, Landeros-Flores J, Hernández-Camacho S, DelgadoOrtiz J.C. 2012. Evaluación in vitro de la actividad antifúngica de cuatro extractos vegetales metanólicos para el control de tres especies de Fusarium spp. Phyton, 81:69-73.

15. Oliveira-Filho AA, Fernandes HMB, Assis TJCF. 2015. Lauraceae's Family: A Brief Review of Cardiovascular Effects. International Journal of Pharmacognosy and Phytochemical Research, 7: 22-26.

16. Pagotto CLAC, Barros JRT, Borin MRMB, Gottlieb OR. 1998. Quantitative chemical biology II. Chemical mapping of Lauraceae. Anais da Academia Brasileira Ciências, 70:1705-9.

17. Palazzo MC, Agius BR, Wright BS, Haber WA, Moriarity DM, Setzer WN. 2009. Chemical compositions and cytotoxic activities of leaf essential oils of four Lauraceae tree species from Monteverde, Costa Rica. Records of Natural Products, 3:32-37.

18. Parveen Z, Nawaz S, Siddique S, Shahzad K. 2013. Composition and Antimicrobial Activity of the Essential Oil from Leaves of Curcuma longa L. Kasur Variety. Indian Journal of Pharmaceutical Sciences, 75:117-122.
19. Pino, JA, Rodríguez, DK, Beldarraín T, Blandariz SR. 2014. Chemical composition and antibacterial activity of the essential oil of Nectandra antillana Meisn. leaves from Cuba. Journal of Essential Oil Research, 26:359-362.

20. Takaku S, Haber W, Setzer W. 2007. Leaf essential oil composition of 10 species of Ocotea (Lauraceae) from Monteverde, Costa Rica. Biochemical Systematics and Ecology, 35:525-532.

21. Terzi V, Morcia C, Faccioli P, Vale G, Tacconi G., Malnati M. 2007. In vitro antifungal activity of the tea tree (Melaleuca alternifolia) essential oil and its major components against plant pathogens. Letters in Applied Microbiology, 44:613-618.

22. Torres AM, Ricciardi GAL, Agrelo de Nassif AE, Ricciardi AIA, Dellacassa E. 2005. Examen del Aceite esencial de Nectandra angustifolia (Schrad.) Nees \& Mart. ex Nees. Comunicaciones Científicas y Tecnológicas - Uiversidad Nacional del Nordeste, E-013:1-3.

23. Tyagi AK, Malik A. 2010. Liquid and vapourphase antifungal activities of selected essential oils against Candida albicans: microscopic observations and chemical characterization of Cymbopogon citratus. BMC Complementary and Alternative Medicine, 10:65.

24. Unlu M, Ergene E, Unlu GV, Zeytinoglu HS, Vural N. 2010. Composition, antimicrobial activity and in vitro cytotoxicity of essential oil from Cinnamomum zeylanicum Blume (Lauraceae). Food and chemical toxicology : an international journal, 48:3274-3280

25. van der Werff H, Richter HG. 1996. Toward an Improved Classification of Lauraceae. Annals of the Missouri Botanical Garden, 83:409-418. 